\title{
RESEARCH ON REDUCING ALKALINITY OF AN ECOLOGICAL POROUS CONCRETE MIXURE WITH CARBONIZATION
}

\author{
RAZISKAVA ZMANJŠANJA ALKALNOSTI EKOLOŠKE POROZNE \\ BETONSKE MEŠANICE S KARBONIZACIJO
}

\author{
Sheng $\mathrm{Li}^{1,2}$, Jian Yin ${ }^{1 *}$, Gui Zhang ${ }^{1}$, Ting Gao ${ }^{1}$ \\ ${ }^{1}$ College of Civil Engineering, Central South University of Forestry and Technology, Changsha 410018, China \\ ${ }^{2}$ Key Laboratory for Green and Advanced Civil Engineering Materials and Application Technology of Hunan Province, College of Civil \\ Engineering, Hunan University, Changsha, Hunan 410082, China \\ Prejem rokopisa - received: 2018-11-22; sprejem za objavo - accepted for publication: 2019-02-25
}

doi:10.17222/mit.2018.251

In this article, XRD was utilized to analyze the alkalinity affecting the pore size of an ecological porous concrete mixture (EPCM). Variations in the pore alkalinity and compressive strength of the EPCM with different mineral admixtures were investigated using accelerated carbonization and natural carbonization. The experimental results demonstrate that the content of calcium hydroxide is positively related to the $\mathrm{pH}$ value of EPCM pores and both indexes increase with age. Combining accelerated carbonization and additions of mineral admixtures considerably reduced alkalinity and showed no harmful effect on the compressive strength. The lowest $\mathrm{pH}$ value (8.57) was achieved after $56 \mathrm{~d}$ and the compressive strength was slightly improved. Having such an environment, tall fescue can grow in an EPCM and the height of plants is more than $15 \mathrm{~cm}$ on the 56 th day.

Keywords: alkalinity, carbonation, compressive strength, ecological porous concrete mixture, mineral admixtures

Avtorji opisujejo analizo sestave ekološke porozne mešanice betona (EPCM) z rentgensko difrakcijo (XRD), da bi ugotovili vpliv alkalnosti mešanice na njeno poroznost. Ugotavljali so spreminjanje alkalnosti por in tlačne trdnosti EPCM zaradi naravne in pospešene karbonizacije (prepihavanje $\mathrm{s} \mathrm{CO}_{2}$ ) ter pri domešavanju različnih mineralnih dodatkov. Eksperimentalni rezultati so pokazali, da vsebnost kalcijevega hidroksida pozitivno vpliva na $\mathrm{pH}$ vrednost v EPCM in njegovih porah in da oba indeksa naraščata s staranjem mešanic. Kombiniranje pospešene karbonizacije in dodajanja mineralnih dodatkov je močno znižalo alkalnost, vendar ni imelo škodljivega vpliva na tlačno trdnost betona. Najnižjo pH vrednost $(8,57)$ so dosegli po 56 dneh staranja betona in tlačna trdnost se je rahlo izboljšala. Preizkusi rasti trave na EPCM podlagi s $30 \%$ dodatkom dimniškega pepela so pokazali, da le-ta zraste dokaj visoko in sicer več kot $15 \mathrm{~cm}$ v 56-tih dneh.

Ključne besede: alkalnost, karbonizacija, tlačna trdnost, ekološka porozna mešanica betona, mineralni dodatki

\section{INTRODUCTION}

The EPCM is an environmentally friendly concrete, in which plants can grow. The skeleton structure of the EPCM is made of a coarse aggregate with a large particle size and many pores. Then, as the pores are filled with nutrients prepared for plants, the roots of plants can continuously grow through the pore. When used for a city pavement, parking area or the revetment of an expressway, it can improve the city's atmospheric environment, vegetation coverage and has promising application prospects. ${ }^{1-4}$

However, calcium hydroxide in concrete causes interior alkalinity of the pores, making the $\mathrm{pH}$ value rise to $12-13$, which is very harmful to the growth of pavement plants and aquatic plants. ${ }^{5}$ Numerous traditional alkali-reducing technologies, such as adding additives, can effectively reduce the alkalinity of concrete but, at the same time, its mechanical properties are remarkably lower than those of ordinary porous concrete. ${ }^{6}$ In addition, by soaking the EPCM in an oxalic acid solution, the

*Corresponding author's e-mail:

350489714@qq.com oxalic acid reacts with the alkaline substances in the EPCM, reducing the alkali content, which also has an adverse influence on the strength of the EPCM. Some scholars added fly ash, silica fume and other mineral admixtures into the EPCM to reduce the alkali content, but the reduction efficiency was low. ${ }^{7-9}$ Other scholars prevented an alkali release with wax-sealing treatment used on the surfaces of the internal pores of the EPCM, but the effect of alkali reduction was not obvious. ${ }^{10}$ The carbonation of concrete is a complex physical and chemical process, in which carbon dioxide from air interacts with alkaline substances. This process can be simply described with Equation (1):

$$
\begin{gathered}
\mathrm{CO}_{2}+\mathrm{H}_{2} \mathrm{O}=\mathrm{H}_{2} \mathrm{CO}_{3} \\
\mathrm{Ca}(\mathrm{OH})_{2}+\mathrm{H}_{2} \mathrm{CO}_{3}=\mathrm{CaCO}_{3}+2 \mathrm{H}_{2} \mathrm{O}
\end{gathered}
$$

Carbon dioxide from air usually penetrates the interior of concrete through tiny pores or cracks on the surface, interacting with hydrated products such as calcium hydroxide and forming calcium silicate. Then, the chemical composition of concrete is changed. Most importantly, the amount of alkalinity from calcium hydroxide in concrete decreases. ${ }^{11}$ Although carbonation impairs the durability of reinforced concrete, it can 
reduce the alkali content and improve the strength of plain concrete. However, the EPCM does not use reinforcement, and the growth of plants requires low alkalinity in the pore interior of the EPCM. Therefore, it is theoretically feasible to reduce the alkalinity of the EPCM with an accelerated-carbonization test; mineral admixtures also have a certain degree of influence on the carbonation resistance of concrete. ${ }^{12,13}$ Based on three factors including the carbonization method, carbonization age and mineral-admixture content, the alkalireduction technology of the EPCM will be further studied in this paper.

\section{MATERIALS AND METHODS}

\subsection{Raw materials}

The cement used in this research was produced by China Wannianqing Cement Co., Ltd. P.O 42.5 cement was selected; its performance indexes are shown in Table 1 and the details of mineral admixtures are shown in Table 2. There was only single-sized coarse aggregate, no fine aggregate. A coarse aggregate with a particle size of 19-26.5 mm was adopted for this research.

Table 1: Performance indexes of cement

\begin{tabular}{|c|c|c|c|c|c|c|c|c|}
\hline $\begin{array}{c}\mathrm{SSA} \\
/ \mathrm{m}^{2} / \mathrm{kg}\end{array}$ & $\begin{array}{c}\mathrm{SO}_{3} \\
/ \%\end{array}$ & $\begin{array}{c}\text { Stabil- } \\
\text { ity }\end{array}$ & $\begin{array}{c}\mathrm{IS} \\
/ \mathrm{min}\end{array}$ & $\begin{array}{c}\mathrm{FS} \\
/ \mathrm{min}\end{array}$ & $\begin{array}{c}3 \mathrm{~d} \text { FS } \\
/ \mathrm{MPa}\end{array}$ & $\begin{array}{c}3 \mathrm{~d} \mathrm{CS} \\
/ \mathrm{MPa}\end{array}$ & $\begin{array}{c}28 \mathrm{~d} \\
/ \mathrm{MPa}\end{array}$ & $\begin{array}{c}28 \mathrm{~d} \\
\mathrm{CS}\end{array}$ \\
\hline 355 & 2.42 & $\begin{array}{c}\text { quali- } \\
\text { fied }\end{array}$ & 155 & 210 & 5.7 & 25.3 & 8.9 & 53.0 \\
\hline
\end{tabular}

Note $:$ SSA = specific surface area; IS = initial setting; $F S=$ final setting; $3 \mathrm{~d}$ FS $=3 \mathrm{~d}$ flexural strength; $3 \mathrm{~d} \mathrm{CS}=3 \mathrm{~d}$ compressive strength

Table 2: Performance indexes of mineral admixtures

\begin{tabular}{|c|c|c|c|c|c|c|c|}
\hline $\begin{array}{c}\text { Mineral } \\
\text { admixture }\end{array}$ & $\begin{array}{c}\text { Fineness } \\
/ \%\end{array}$ & $\begin{array}{c}\text { LOI } \\
/ \%\end{array}$ & $\begin{array}{c}\text { WDR } \\
/ \%\end{array}$ & $\begin{array}{c}\mathrm{SD} \\
/ \mathrm{g} / \mathrm{cm}^{3}\end{array}$ & $\begin{array}{c}\mathrm{MC} \\
/ \%\end{array}$ & $\begin{array}{c}7 \mathrm{~d} \text { AI } \\
/ \%\end{array}$ & $\begin{array}{c}28 \mathrm{~d} \\
\mathrm{AI} \\
/ \%\end{array}$ \\
\hline Fly ash & 23.33 & 3.8 & 92 & 2.22 & 0.1 & 69 & 96 \\
\hline Slag & 6.07 & 0.9 & 80 & 2.51 & 0.1 & 95 & 98 \\
\hline
\end{tabular}

Note $:$ LOI $=$ loss on ignition; $\mathrm{WDR}=$ water demand ratio; $\mathrm{SD}=$ stacking density; $\mathrm{MC}=$ moisture content; $7 \mathrm{~d} \mathrm{AI}=7 \mathrm{~d}$ activity index; $28 \mathrm{~d} \mathrm{AI}=28 \mathrm{~d}$ activity index

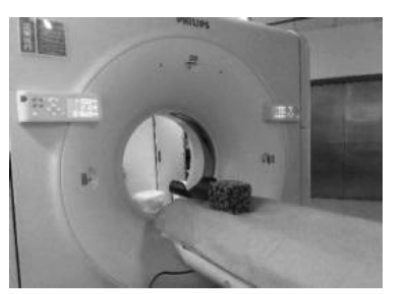

CT scanning test

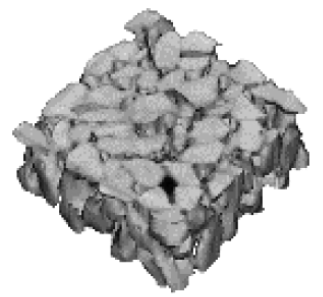

Step 1

\subsection{Experimental part}

\subsubsection{Preparation simulation}

For the plants to have enough pores to grow in the EPCM, the effective porosity (20-35\%) and compressive strength after $28 \mathrm{~d}(5-15 \mathrm{MPa})$ were used as the control criteria. The W/C for the EPCM was 0.30. In order to study the influence of mineral admixtures on the alkalinity of eco-porous concrete, fly ash and slag were mixed into the EPCM.

\subsubsection{Specimen preparation}

Fly ash and slag were used to replace the cement in the amounts of $(0,10,20$ and 30$) \%$. We used the improved "paste-coating-gravel" method, that is, we mixed the cement, mineral admixtures and $70 \%$ of water in a blender for $1.5 \mathrm{~min}$, then we mixed the coarse aggregates for $1 \mathrm{~min}$, and added the remaining $30 \%$ of water, mixing it for $1 \mathrm{~min}^{14}$ The mixture was poured into a mold in three layers. After each layer was poured, a vibrating bar was used to ensure a good compaction effect and the specimens were demolded $24 \mathrm{~h}$ after having been casted (in Figure 1, a 3D model was used to show the EPCM molding process. Based on the images of the EPCM scanned with CT, the pore structure of the EPCM could be reconstructed with Mimics 15.0, and a clear three-dimensional model was obtained. Then, a three-dimensional fault model of the EPCM with a designated thickness could be obtained using a threedimensional cutting angle. According to Chinese specification GB/T 50081-2009, the dimensions of a specimen for the compression test and alkalinity test were

Table 3: Mix proportion of the EPCM

\begin{tabular}{|c|c|c|c|c|c|c|}
\hline Batch & $\begin{array}{c}\text { Grain } \\
\text { size } \\
/ \mathrm{mm}\end{array}$ & $\begin{array}{c}\text { Cement } \\
/ \mathrm{kg} / \mathrm{m}^{3}\end{array}$ & $\begin{array}{c}\text { Water } \\
/ \mathrm{kg} / \mathrm{m}^{3}\end{array}$ & $\begin{array}{c}\mathrm{FA} \\
/ \mathrm{kg} / \mathrm{m}^{3}\end{array}$ & $\begin{array}{c}\mathrm{SG} \\
/ \mathrm{kg} / \mathrm{m}^{3}\end{array}$ & $\begin{array}{c}\text { Water } \\
\text { binder } \\
\text { ratio }\end{array}$ \\
\hline A1/B1 & $19 \approx 26.5$ & 300 & 90 & 0 & 0 & 0.30 \\
\hline A2/B2 & $19 \approx 26.5$ & 270 & 90 & 30 & 0 & 0.30 \\
\hline A3/B3 & $19 \approx 26.5$ & 240 & 90 & 60 & 0 & 0.30 \\
\hline A4/B4 & $19 \approx 26.5$ & 210 & 90 & 90 & 0 & 0.30 \\
\hline A5/B5 & $19 \approx 26.5$ & 270 & 90 & 0 & 30 & 0.30 \\
\hline A6/B6 & $19 \approx 26.5$ & 240 & 90 & 0 & 60 & 0.30 \\
\hline A7/B7 & $19 \approx 26.5$ & 210 & 90 & 0 & 90 & 0.30 \\
\hline
\end{tabular}

Note $: \mathrm{FA}=$ fly ash $; \mathrm{SG}=$ slag

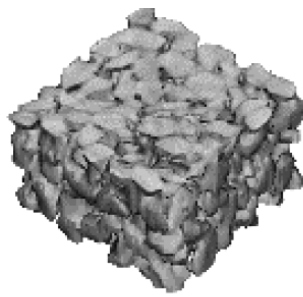

Step 2

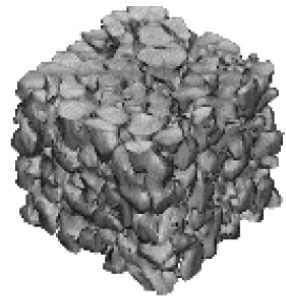

Step 3

Figure 1: CT scanning test and EPCM molding process (3D model) 

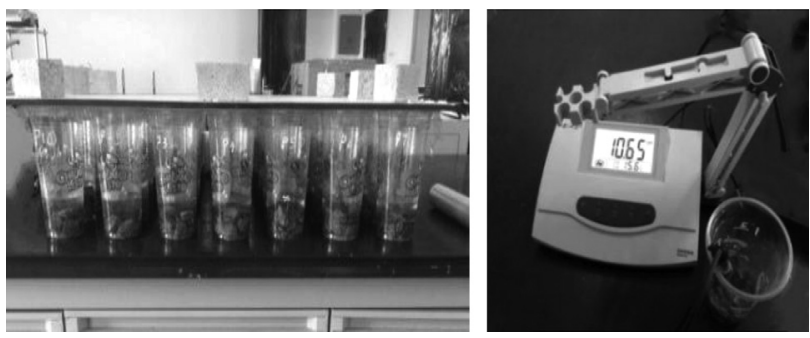

Figure 2: Situation at the testing site

$(150 \times 150 \times 150) \mathrm{mm} \cdot{ }^{15}$ The specimen was solidified in standard condition (the temperature was $20 \pm 2{ }^{\circ} \mathrm{C}$ and the relative humidity was $95 \%$ ) for $28 \mathrm{~d}$. Then, we removed the specimen and put it into an oven and set the temperature to $105{ }^{\circ} \mathrm{C}$, drying it to its constant weight. The mix proportions for the EPCM are presented in Table 3 .

\subsection{Measurement methods}

\subsubsection{Carbonization test}

The test is based on Chinese specification GB/T 50082-2009. ${ }^{15}$ The specimens of group A were placed in a carbonization box for an accelerated carbonization test, and the specimens of group B were placed in the external

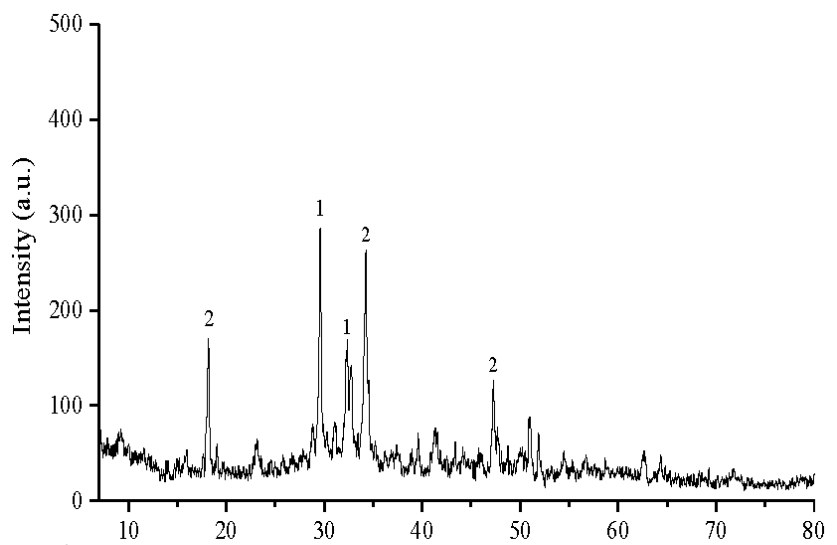

$7 d$

$2 \theta$ (degree)

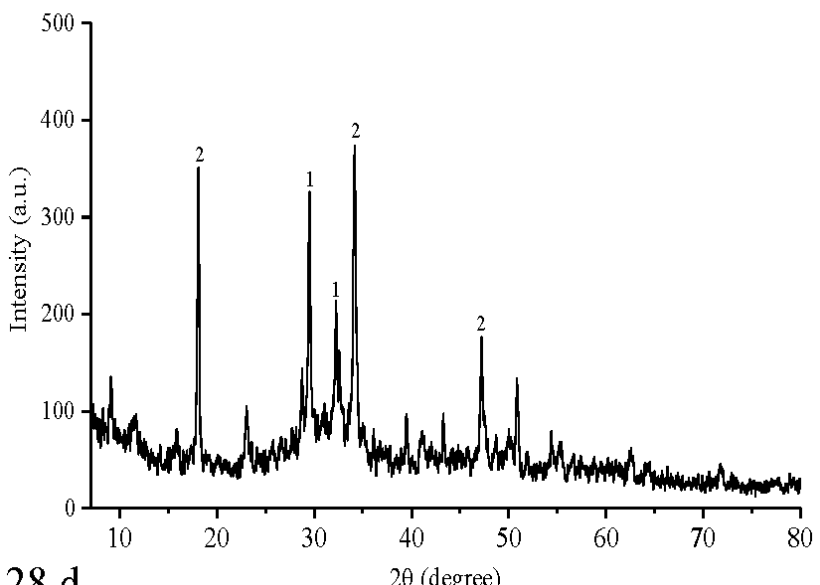

environment for natural-carbonization test. The carbonization ages were $(7,14,28$ and 56) $d$.

\subsubsection{Compressive strength}

A TYE-2000E pressure-testing machine was used to test the compressive strength of the specimens. Assuming the compressive strength of the EPCM is low, the loading rate is $2.25 \mathrm{KN} / 1 \mathrm{~s}$. Compressive strength of the EPCM was determined according to Chinese specification GB/T 50081-2009. ${ }^{15}$

\subsubsection{Alkalinity test}

The alkalinity of the internal pores of the EPCM was determined using the alkalinity-release principle. ${ }^{16}$ The steps of the alkalinity test were as follows: after crushing a specimen, we weighed 100-g fragments and put them into a cup; we added $100 \mathrm{ml}$ of water to ensure that the fragments were immersed in water, and then we sealed the cup mouth with a fresh-keeping film to prevent water evaporation. After $24 \mathrm{~h}$ of immersion, a PHS-3E pH tester was used to test the $\mathrm{pH}$ value of the water solution of the immersed sample, and then we replaced fresh water to immerse it for another $24 \mathrm{~h}$ to continue the test until the data become stable. The situation at the testing site is shown in Figure 2.
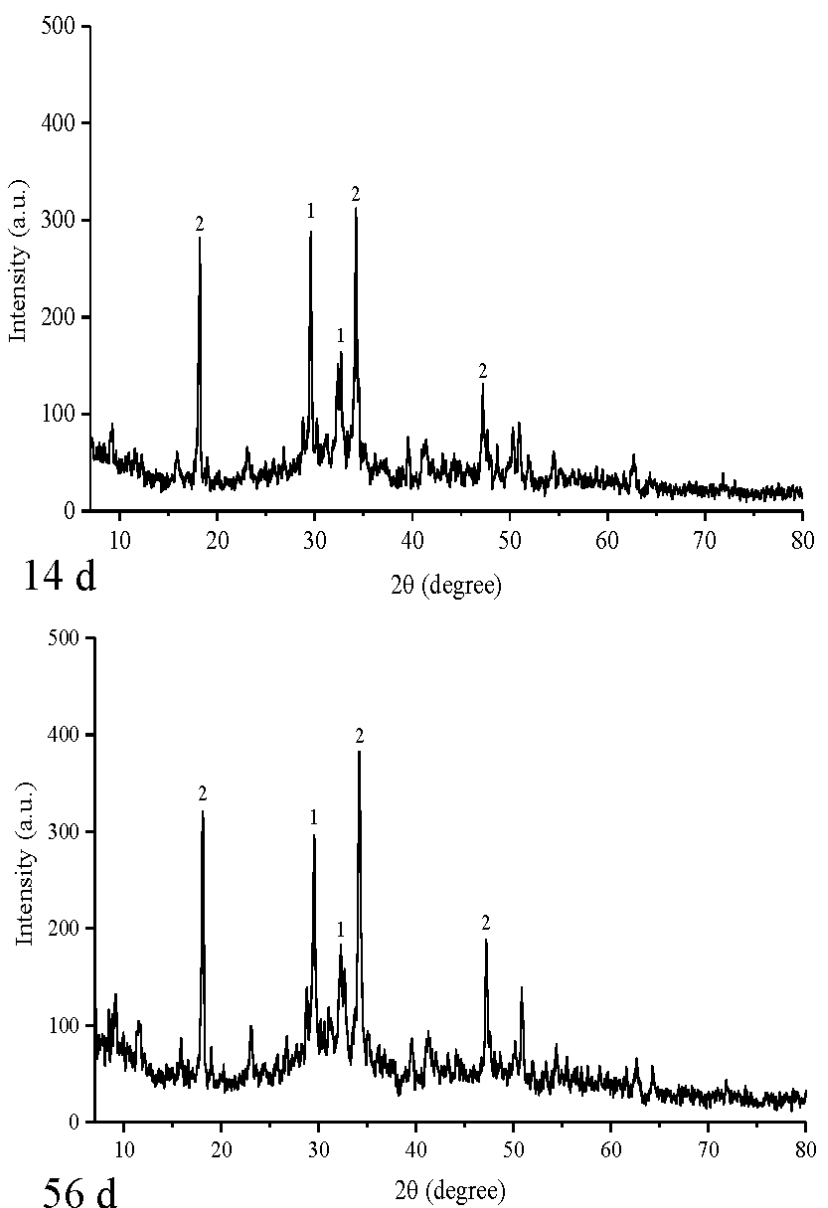

Figure 3: XRD diffraction analysis of EPCM surface cement (Note: 1 = calcium carbonate; 2 = calcium hydroxide) 

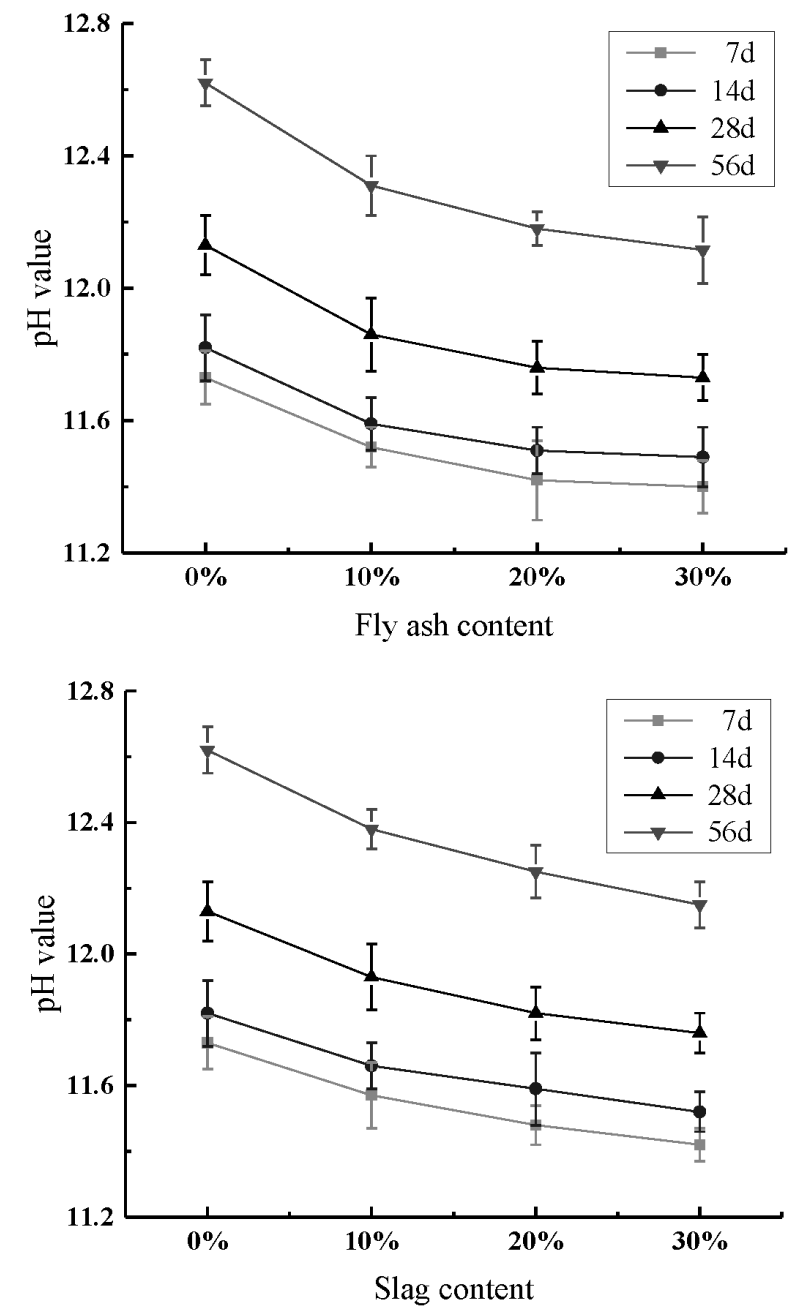

Figure 4: Influence of mineral admixtures on alkalinity of EPCM

\subsubsection{Vegetation test}

According to the existing research data of the research group, tall fescue is a subtropical plant with the advantages of cold resistance, heat resistance and trampling resistance. The fibrous roots of tall fescue are hard, easily penetrating the inner pores of the EPCM; the diameter of its rhizome is small, having little effect on the pore structure of the EPCM during the root growth. Therefore, tall fescue was chosen as the experimental grass species that should be watered regularly during the germination process.

\section{RESULTS AND DISCUSSION}

\subsection{Influence of mineral admixtures on the EPCM alkalinity}

The main characteristic parameter of the alkalinity of the EPCM is the calcium hydroxide content. The cement on the EPCM surface cured for (7, 14, 28 and 56) d was ground into powder, and XRD was used for a diffraction analysis. Figure 3 shows the analysis results. The content of calcium hydroxide produced due to cement hydration and the $\mathrm{pH}$ value in the EPCM pores increase with age, indicating that the former is positively related to the latter.

Figure 4 shows the influence of mineral admixtures on the alkalinity of the EPCM. With an increase in the fly ash or slag content, the alkalinity of the EPCM tends to decrease; fly ash has a better alkali-reducing ability than slag, and the maximum decrease occurs after $56^{\text {th }}$ day. The hydration reaction of the EPCM produces hydrated calcium silicate gel and calcium hydroxide. The principal components of the mineral admixture are silica

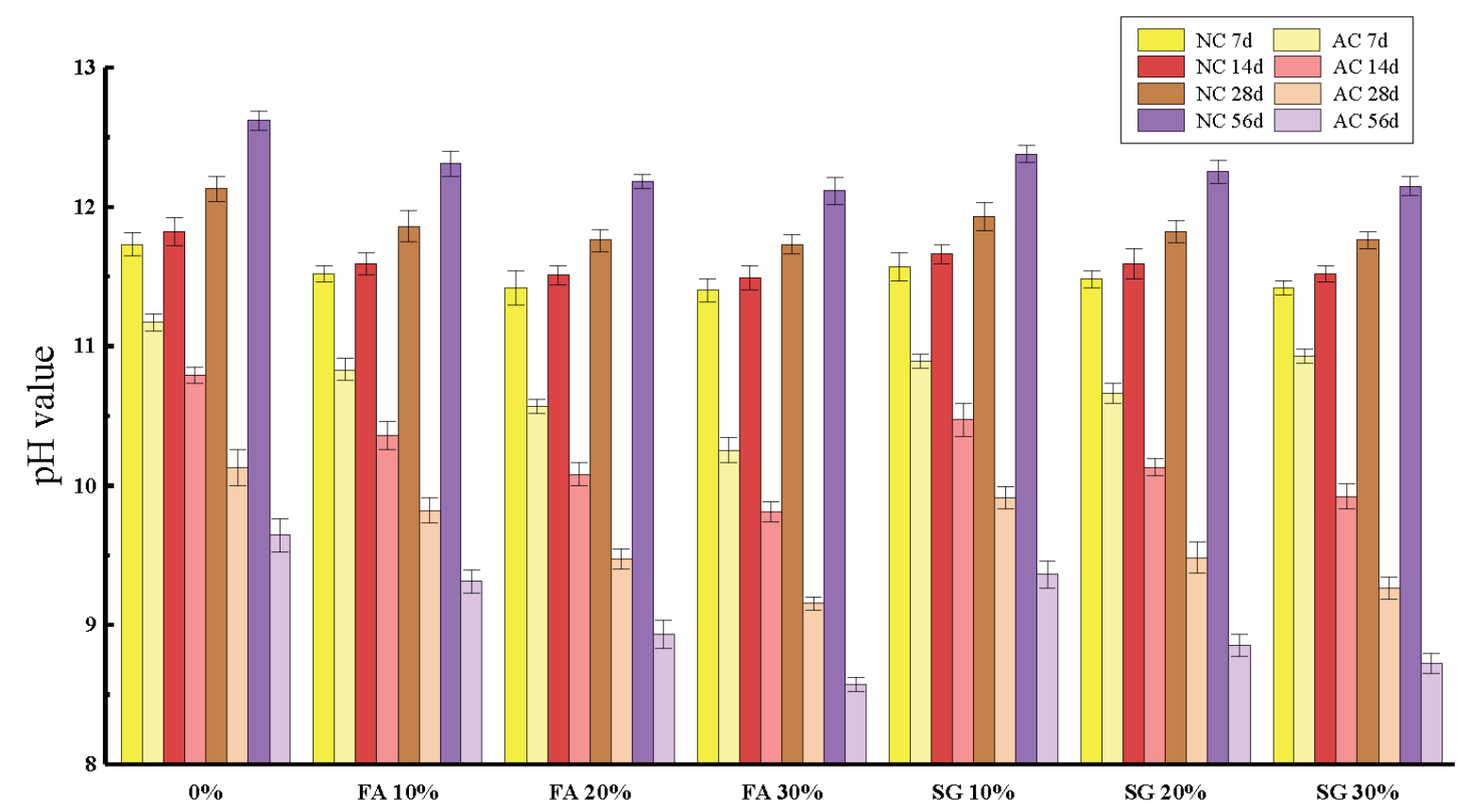

Figure 5: Alkalinity of EPCM after accelerated carbonization and natural carbonization Note $: \mathrm{NC}=$ natural carbonization; $\mathrm{AC}=$ accelerated carbonization 


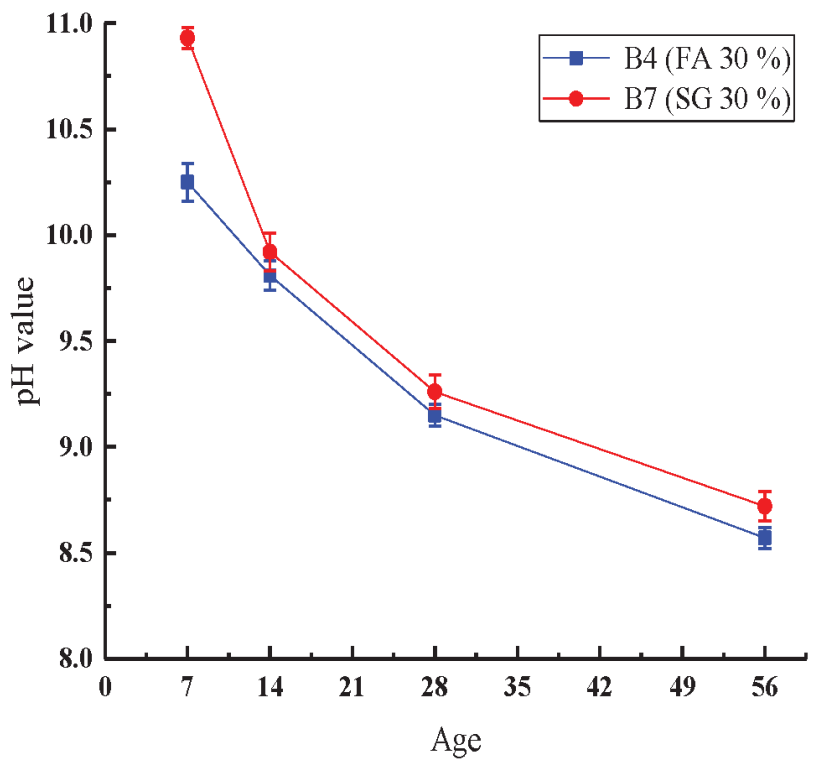

Figure 6: Relationship between the alkalinity and carbonization age of EPCM

and calcium oxide. Activated silica and alumina can react with calcium hydroxide to form calcium silicate gel, thereby reducing the incidence of calcium hydroxide. With the increase of the mineral-admixture content, the content of active silica increases and the consumption of calcium hydroxide increases, which makes the $\mathrm{pH}$ value of the EPCM decrease. However, the effect of adding mineral admixtures on the alkali reduction is limited. The $\mathrm{pH}$ value of mineral admixtures in each age group is still around 11-13, which is far from meeting the requirements for plant growth.

\subsection{Influence of carbonation and mineral admixture on the alkalinity of the EPCM}

The test results of the $\mathrm{pH}$ values of the EPCM for two carbonization methods and different carbonization ages are shown in Figure 5. It can be seen that the $\mathrm{pH}$ value of the EPCM after accelerated carbonization decrease significantly. The $\mathrm{pH}$ value of the EPCM with the same mix ratio decreases by about $0.49-1.15$ units after $7 \mathrm{~d}$ of accelerated carbonization compared with that after $7 \mathrm{~d}$ of natural carbonization; after $56 \mathrm{~d}$ of accelerated carbonization, the $\mathrm{pH}$ value decreases by about 2.98-3.55 units. This is because carbon dioxide gas permeates into the pores and surface of the EPCM and reacts with alkaline substances such as calcium hydroxide in the EPCM to form carbonate and water, changing the chemical composition and micro-structure of the EPCM and reducing its alkalinity. The data show that the concentration of carbon dioxide in the atmosphere of some parts of China reaches $388 \mathrm{ppm}(0.038 \%)$, while the concentration of carbon dioxide in the accelerated carbonization test reaches about $20 \%$, and the relative humidity remains at $70 \%$.

Under the accelerated carbonization test environment, the carbonization rate of the porous EPCM will be greatly accelerated and the alkalinity will be considerably reduced. It can also be seen from Figure 5 that with the increase in the carbonization time, the decreasing trend of the $\mathrm{pH}$ value slows down, which indicates that the effect of carbonization on the $\mathrm{pH}$ value of the pore environment in the EPCM is limited. Under the action of a low-content mineral admixture, the $\mathrm{pH}$ value of slag-mixed specimens in the early stage of carbonization is lower than that of fly-ash-mixed specimens; thus, the opposite result is presented in the later stage of carbonization. Under the action of a high-content mineral admixture, the $\mathrm{pH}$ value of fly-ash specimens is lower than that of slag specimens.

After $56 \mathrm{~d}$ of accelerated carbonization, the $\mathrm{pH}$ value of groups B4 and B7 decreased to 8.57 and 8.72, respectively, meeting the requirement for the $\mathrm{pH}$ value of plant growth to be 7-9. This indicated that the alkalinity of the EPCM internal pores was sharply reduced by the coupling effect of mineral admixture and accelerated carbonization. In accordance with the data, two curve formulas can be fitted to describe the relationship between the carbonization time and alkalinity. Equation (2) refers to the B4 group, Equation (3) refers to the B7 group and detailed curves are shown in Figure 6.

$$
\begin{array}{ll}
P=12.202 \mathrm{D}^{-0.087} & R^{2}=0.9333 \\
P=13.406 \mathrm{D}^{-0.109} & R^{2}=0.9326
\end{array}
$$

Here, $P$ is the $\mathrm{pH}$ value and $D$ is the age of accelerated carbonization.

\begin{tabular}{|c|c|c|c|c|c|c|c|c|c|}
\hline \multirow[t]{3}{*}{ Batch } & SC $28 \mathrm{~d}$ & \multicolumn{8}{|c|}{ Compressive strength/MPa } \\
\hline & & $7 \mathrm{~d}$ & $14 \mathrm{~d}$ & $28 \mathrm{~d}$ & & & $56 \mathrm{~d}$ & & \\
\hline & & $\mathrm{AC}$ & $\mathrm{NC}$ & $\mathrm{AC}$ & $\mathrm{NC}$ & $\mathrm{AC}$ & $\mathrm{NC}$ & $\mathrm{AC}$ & $\mathrm{NC}$ \\
\hline $\mathrm{A} 1 / \mathrm{B} 1$ & $8.9(0.4)$ & $9.3(0.2)$ & $9.1(0.1)$ & $9.7(0.3)$ & $9.2(0.5)$ & $10.7(0.6)$ & $9.8(0.8)$ & $11.0(0.7)$ & $10.0(0.4)$ \\
\hline $\mathrm{A} 2 / \mathrm{B} 2$ & $9.1(0.3)$ & $9.6(0.6)$ & $9.3(0.4)$ & $9.8(0.7)$ & $9.4(0.1)$ & $11.0(0.3)$ & $10.2(0.5)$ & $11.4(0.4)$ & $10.4(0.6)$ \\
\hline A3/B3 & $9.1(0.5)$ & $9.7(0.1)$ & $9.5(0.4)$ & $10.0(0.5)$ & $9.5(0.2)$ & $10.9(0.2)$ & $10.4(0.3)$ & $11.5(0.5)$ & $10.5(0.3)$ \\
\hline A4/B4 & $9.0(0.2)$ & $9.9(0.2)$ & $9.6(0.6)$ & $9.8(0.2)$ & $9.5(0.7)$ & $11.5(0.4)$ & $10.5(0.4)$ & $11.9(0.2)$ & $10.7(0.2)$ \\
\hline A5/B5 & $8.7(0.6)$ & $9.5(0.4)$ & $9.3(0.3)$ & $9.4(0.5)$ & $9.6(0.4)$ & $10.9(0.2)$ & $10.5(0.1)$ & $11.0(0.1)$ & $10.6(0.2)$ \\
\hline A6/B6 & $9.1(0.1)$ & $9.5(0.3)$ & $9.4(0.5)$ & $9.6(0.2)$ & $9.7(0.2)$ & $11.0(0.1)$ & $10.7(0.6)$ & $11.3(0.6)$ & $11.0(0.1)$ \\
\hline A7/B7 & $8.8(0.2)$ & $9.7(0.4)$ & $9.4(0.1)$ & $9.7(0.5)$ & $9.8(0.5)$ & $11.4(0.2)$ & $10.8(0.2)$ & $11.7(0.3)$ & $11.1(0.5)$ \\
\hline
\end{tabular}

Table 3: Compressive strength of EPCM after two carbonation methods

Note $: \mathrm{SC}=$ standard curing; $\mathrm{AC}=$ accelerated carbonization; $\mathrm{NC}=$ natural carbonization 


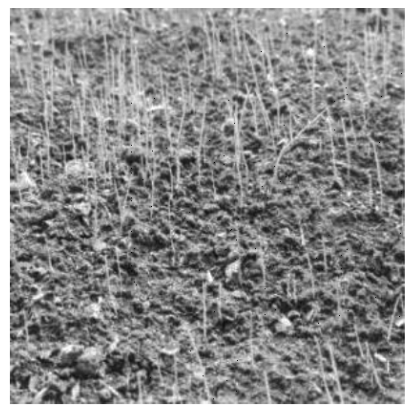

$3 \mathrm{~d}$

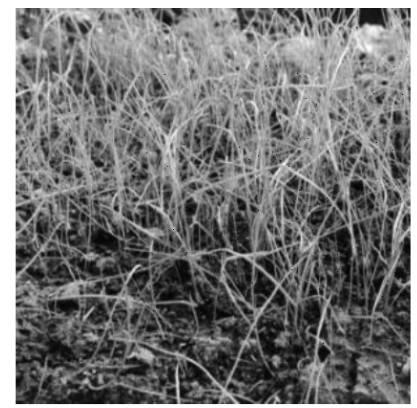

$28 \mathrm{~d}$

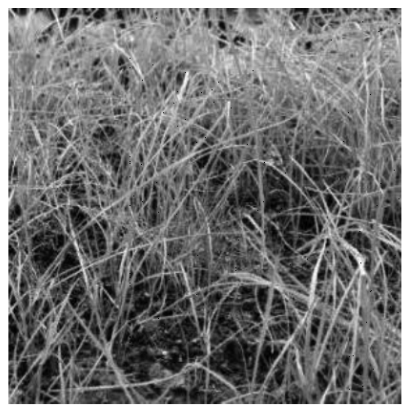

$56 \mathrm{~d}$

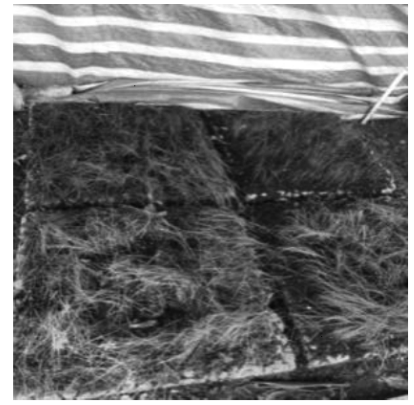

$56 \mathrm{~d}$

Figure 7: Growth of fescue in the EPCM

\subsection{Influence of carbonation and mineral admixture on the compressive strength of the EPCM}

Table 3 shows the effects of two carbonization methods on the compressive strength of the EPCM. The compressive strength of the EPCM is increased by 1.9-2.6 MPa compared with that of the EPCM cured for standard $28 \mathrm{~d}$ after accelerated carbonization. Compared with natural carbonization, the strength of the EPCM after accelerated carbonization for $56 \mathrm{~d}$ is enhanced by 2-11.2\%

There are two main effects of carbonization: 1) the water released during carbonization can further hydrate the unhydrated cement particles, and the calcium hydroxide in the cement paste absorbs carbon dioxide from air to form calcium carbonate crystals, which can fill the pores and compact the microstructure of the EPCM; 2) the reduction of alkalinity caused by carbonization results in a decomposition of a certain proportion of the C-S-H gel, which may decrease the compressive strength of the EPCM. From the overall trend, the first effect overtakes the second one. Consequently, the compressive strength is increased. Mineral admixtures also improve the compressive strength of the EPCM and the bigger their amount, the larger is the strength improvement. This is due to the physical filling effect of the mineral admixture. At the same time, active silica and alumina in the admixture react with calcium hydroxide to form hydrate products. These hydrate products can also effectively fill in the pores between cement particles and improve the interface transition zone of the EPCM. The results demonstrate that the mechanical properties of the EPCM can be improved with a combination of a mineral admixture and carbonization test.

\subsection{Vegetation test of the EPCM}

Grass planting was carried out using the EPCM mixed with $30 \%$ FA and 56-day accelerated carbonization. Figure 7 shows the growth of tall fescue after (3, 28 and 56) d. The growth was observed. The roots of tall fescue began to germinate on the $3^{\text {rd }}$ day; on the $28^{\text {th }}$ day, the roots penetrated the pores of the EPCM and tall fescue was rooted in the bottom soil. On the $56^{\text {th }}$ day, the height of tall fescue exceeded $15 \mathrm{~cm}$. This suggests that tall fescue grows well in the EPCM treated with mineral admixtures and the appropriate carbonation method.

\section{CONCLUSIONS}

By studying the effects of two carbonization methods and mineral admixtures on the pore alkalinity and compressive strength of the EPCM, the following conclusions are drawn:

The content of calcium hydroxide produced due to cement hydration and the $\mathrm{pH}$ value of the EPCM pores increase with age, indicating that the former is positively related to the latter.

2) Adding mineral admixtures such as fly ash or slag can reduce the alkalinity of the EPCM, but the common amount of the mixture (10-30\%) is not enough to achieve the required $\mathrm{pH}$ value for a plant-growth environment. It must be combined with other alkalireducing technologies.

3) Coupling the addition of mineral admixtures and accelerated carbonization can significantly reduce the alkalinity of the EPCM pores. After $56 \mathrm{~d}$ of accelerated carbonization, the $\mathrm{pH}$ value can be decreased to 8.57, which is suitable for plant growth.

4) The compressive strength of the EPCM increases by $2-11.2 \%$ after accelerated carbonization, indicating that the accelerated-carbonization technology can be applied to the EPCM.

5) Tall fescue grew well in the EPCM (30\% FA and 56-d accelerated carbonation); its roots began to germinate on the $3^{\text {rd }}$ day. On the $56^{\text {th }}$ day, the height of the tall fescue planted in the EPCM exceeded $15 \mathrm{~cm}$.

\section{Acknowledgments}

The authors greatly appreciate the support of The National Key Research and Development Program of China (Project No.: 2016YFC0700801-01) and The Hunan Province Science and Technology Department (Project No.: 2013FJ2002, 14JJ4055). This study was also supported by Central South University of Forestry and Technology (CX2017B41). 


\section{REFERENCES}

${ }^{1}$ S. Shen, M. Burton, B. Jobson, L. Haselbach, Pervious concrete with titanium dioxide as a photocatalyst compound for a greener urban road environment, Constr. Build. Mater., 35 (2012) 10, 874-883, doi:10.1016/j.conbuildmat.2012.04.097

${ }^{2}$ R. Yu, P. Spiesz, H. J. H. Brouwers, Development of an eco-friendly ultra-high performance concrete (UHPC) with efficient cement and mineral admixtures uses, Cement and Concrete Composites, 55 (2015) 1, 383-394, doi:10.1016/j.cemconcomp.2014.09.024

${ }^{3}$ B. Huang, H. Wu, X. Shu, E. G. Burdette, Laboratory evaluation of permeability and strength of polymer-modified pervious concrete Constr. Build. Mater., 24 (2010) 5, 818-823, doi:10.1016/ j.conbuildmat.2009.10.025

${ }^{4}$ K.-H. Lee, K.-H. Yang, Development of a neutral cementitious material to promote vegetation concrete, Construction and Building Materials, 127 (2016), 442-449, doi:10.1016/j.conbuildmat.2016. 10.032

${ }^{5}$ L. Xiangzhou, Eco concrete technology for sustainable development, China Building Materials, (2003) 1, 344-350, doi:10.16291/ j.cnki.zgjc.2003.01.016

${ }^{6}$ W. Guiling, W. Longzhi, Z. Haixia, Mixture design, alkalinity control, selection of planting soil and plant for planting eco-concrete, Concrete, (2013) 2, 102-109, doi:10.3969/j.issn.1002-3550.2013. 02.029

${ }^{7}$ H. F. W. Taylor, K. Mohan, G. K. Moir, Analytical study of pure and extended Portland cement pastes: II, Fly-ash- and slag-cement pastes, Journal of the American Ceramic Society, 68 (1985) 12, 685-690, doi:10.1111/j.1151-2916.1985.tb10125.x
${ }^{8}$ M. H. Shehata, M. D. A. Thomas, R. F. Bleszinski, The effects of fly ash composition on the chemistry of pore solution in hydrated cement pastes, Cement and Concrete Research, 29 (1999) 11, 1915-1920, doi:10.1016/S0008-8846(99)00190-8

${ }^{9}$ J. L. Garcia Calvo, A. Hidalgo, Development of low-pH cementitious materials for HLRW repositories: Resistance against groundwater aggression, Cement and Concrete Research, 40 (2010) 8, 1290-1297, doi:10.1016/j.cemconres.2009.11.008

${ }^{10} \mathrm{H}$. Chunming, H. Yongyou, Improvement on alkaline water in the pores of eco-concrete, China Concrete and Cement Products, (2006) 3, 8-10, doi:10.3969/j.issn.1000-4637.2006.03.003

${ }^{11}$ Y. Hongsheng, The study of sensitivity factors for concrete carbonization, Industrial Construction, (2014) 44, 94-97, doi:10.13204/ j.gyjz201401021

${ }^{12}$ L. Wenyu, S. Xian, Study on decreasing alkalinity of planting concrete and the resulting planting effect, Concrete, (2013) 7, 155-158, doi:10.3969/j.issn.1002-3550.2013.07.044

${ }^{13}$ B. Aruhan, Peiyu Yan, Carbonation Characteristics of Concrete with Different Fly-Ash Contents, Journal of the Chinese Ceramic Society, (2011) 1, 7-12, doi:10.14062/j.issn.0454-5648.2011.01.022

${ }^{14} \mathrm{G}$. Zhang, J. Yin, S. Li, Investigation on freeze-thaw resistance of eco-porous concrete containing fly ash, Mater. Tehnol., 52 (2018) 2, 183-188, doi:10.17222/mit.2017.073

${ }^{15}$ Chinese Standard, Standard for Test Method of Mechanical Properties on Ordinary Concrete, 2009

${ }^{16}$ M. Zhiliang, W. Zhongbing, Alkalinity of pore fluid of high-addition fly-ash concrete, Journal of Chongqing University, 21 (1999) 1 , 24-27, doi:10.11835/j.issn.1674-4764.1999.01.006 